\title{
Change in position and altitude of a small outlet glacier during the period 1943-92: Leverett Glacier, West Greenland
}

\author{
Frank G. M. VAN TATENhove, \\ Fysisch Geografisch en Bodemkundig Laboratarium, Universiteil van Amsterdam, Nieuwe Prinsengracht 130, 1018 VZ Amsterdam, \\ The Netherlands
}

Chris M. Roelfsema, Geert Blommers and Anton van Voorden

Faculteil Geodesie, Technische Universiteil Delft, Thijsseweg 11, 2600 GA Delft, The Netherlands

\begin{abstract}
Fluctuations in the position and surface altitude of Leverett Glacier, a small outlet glacier at the western margin of the Greenland ice sheet, are determined from a photogrammetric analysis. During the Greenland Ice-Margin Experiment (GIMEX) 1992 expedition, six control points were measured on the exposed rock surrounding Leverett Glacier, using a distancemeter (AGA 220 Geodimeter) and theodolite (Wild T2). Photogrammetric measurements were carried out on an analytical plotter (Zeiss Planicomp C100). The altitude of points could be photogrammetrically measured with a maximum error of $0.86 \mathrm{~m}$.

The data on the altitude changes of Leverett Glacier presented here are the first in West Greenland that span a time period of nearly 50 years. During the period 1943-68 the rate of altitude change was $-0.6 \mathrm{~m} \mathrm{w} . e . \mathrm{a}^{-1}$. The thickening rate during the period 1968-85 was $+1.2 \mathrm{~m}$ w.e. $\mathrm{a}^{1}$. Thickening continued during the period 198592 at a rate of $+0.4 \mathrm{~m}$ w.e. $\mathrm{a}^{-1}$. This recent thickening is significant when compared to yearto-year variation in ablation. Trends in air temperature from the nearby climate station at Kangerlussuaq are consistent with the possibility that observed changes in the altitude of the glacier surface are the result of local changes in meteorological conditions determining ablation rates.
\end{abstract}

\section{INTRODUCTION}

Leverett Glacier in West Greenland is a small outlet glacier draining the main ice sheet (Fig. 1). Its area is approximately $20 \mathrm{~km}^{2}$, with about $7 \mathrm{~km}^{2}$ surrounded by mountains with a maximum altitude of $562 \mathrm{~m}$ (Fig. 2). In the inventory of West Greenland glaciers, Leverett Glacier has been coded 1DG03002 (Weidick and others, 1992).

There are aerial photographs available from the $1940 \mathrm{~s}, 1960 \mathrm{~s}$ and 1980s of the western margin of the Greenland ice sheet. In the Leverett area, photographs were taken in 1943, 1968 and 1985. Using these, a detailed reconstruction of glacier fluctuations and changes in ice-marginal morphology is possible.

The aims of this paper are to determine changes in surface elevation during the last 50 years in the icemarginal area of West Greenland and to establish an icemarginal area that can be used as reference for remotely sensed altitude determinations. Results on the altitudinal and positional change of Leverett Glacier provide an essential glaciological framework for studying the processes of change in ice-marginal geomorphology.

\section{FIELD SURVEY}

In 1992 there was a glacial geological expedition to Leverett Glacier. This was part of the Dutch research effort in West Greenland, known as the GIMEX project (Greenland Ice-Margin Experiment).

A geodetic net consisting of six natural control points was measured around Leverett Glacier using a distancemeter (AGA 220 Geodimeter) and theodolite (Wild T2). Positioning of the control points was based on the identification of characteristic points on each set of aerial photographs (see Figure 2 for the location of the points). The maximum standard deviations of the positions of the control points (based on repeated levelling) are $3 \mathrm{~cm}$ in the horizontal direction and $10 \mathrm{~cm}$ in the vertical.

A longitudinal and transverse profile on the glacier and 15 points on ice-marginal moraines were surveyed with the same equipment. The positions of these points are less accurate than those of the control points, but are estimated to be more accurate than the most distant point on the longitudinal profile. The maximum standard deviation in the position of this point $\pm 1500 \mathrm{~m}$ from 


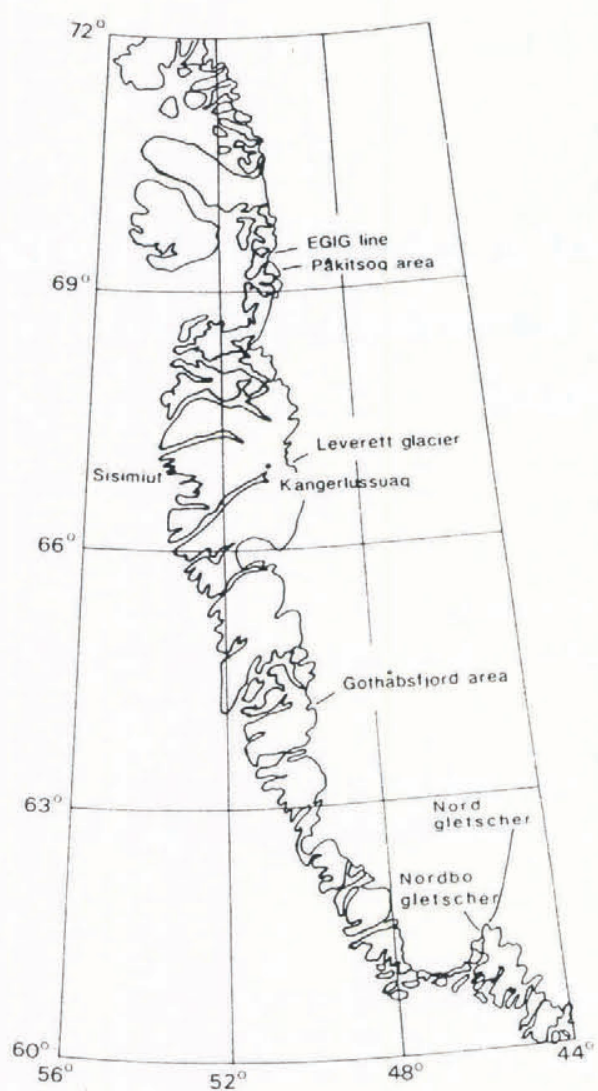

Fig. 1. Location of Leverett Glacier, Kangerlussuaq, Sisimiut and sites where thickness change has been determined from photogrammetric measurements or repeated levelling.

control point 1 ) is $5 \mathrm{~cm}$ in the horizontal and $11 \mathrm{~cm}$ in the vertical.

\section{PHOTOGRAMMETRIC PROGRAMME}

Photogrammetric measurements were carried out on an analytical stereo plotter (Zeiss Planicomp C100) at the Faculty of Geodesy of the Technical University in Delft, The Netherlands. The altitude of coordinates could be measured with an accuracy of $\overline{\mathrm{d} z}<0.86 \mathrm{~m}$, where $\overline{\mathrm{d} z}$ is the square root of the sum of the squared residuals divided by the number of control points. The residuals refer to the differences between the terrain measurements and the photogrammetric stereo model, and include errors introduced by identification of control points on the aerial photographs, film deformation, lens distortion, measuring errors and errors in terrestrial measurements (see Table 1). When subtracting altitude measurements of different years, we assume that errors in elevation are

Table 1. Information about aerial photographs of 1943, 1968 and 1985 and accuracy of $x, y$ and $z$ coordinates obtained with photogrammetry

\begin{tabular}{llll}
\hline & 1943 & 1968 & 1985 \\
$\begin{array}{c}\text { Camera report } \\
\text { available? }\end{array}$ & no & yes & yes \\
$\begin{array}{c}\text { Photo scale } \\
\text { Base/height ratio }\end{array}$ & $1: 39700$ & $1: 47400$ & $1: 161700$ \\
$\begin{array}{c}\text { Flight altitude } \\
(\mathrm{m})\end{array}$ & 5670 & 6920 & $1: 1340$ \\
$\begin{array}{c}\text { Focal length } \\
(\text { mm })\end{array}$ & 152.40 & 152.52 & 87.72 \\
$\begin{array}{c}\text { Overlap } \%) \\
\text { Date of } \\
\text { photography }\end{array}$ & 57 & 34 & 62 \\
& ? June & 17 August & 7 September \\
\end{tabular}

Estimated accuracy of photogrammetric measurements

$\begin{array}{cccc} & \mathrm{m} & \mathrm{m} & \mathrm{m} \\ \overline{\mathrm{d} x} & 2.66 & 1.56 & 2.70 \\ \overline{\mathrm{d} y} & 3.47 & 2.92 & 3.01 \\ \mathrm{~d} z & 0.86 & 0.16 & 0.40 \\ \sigma_{0} & 3.98 & 2.47 & 3.00\end{array}$

† The exact date is not known. We estimate that the photograph was taken before mid-summer and after March-April since lake ice is breaking up and snow is almost absent.

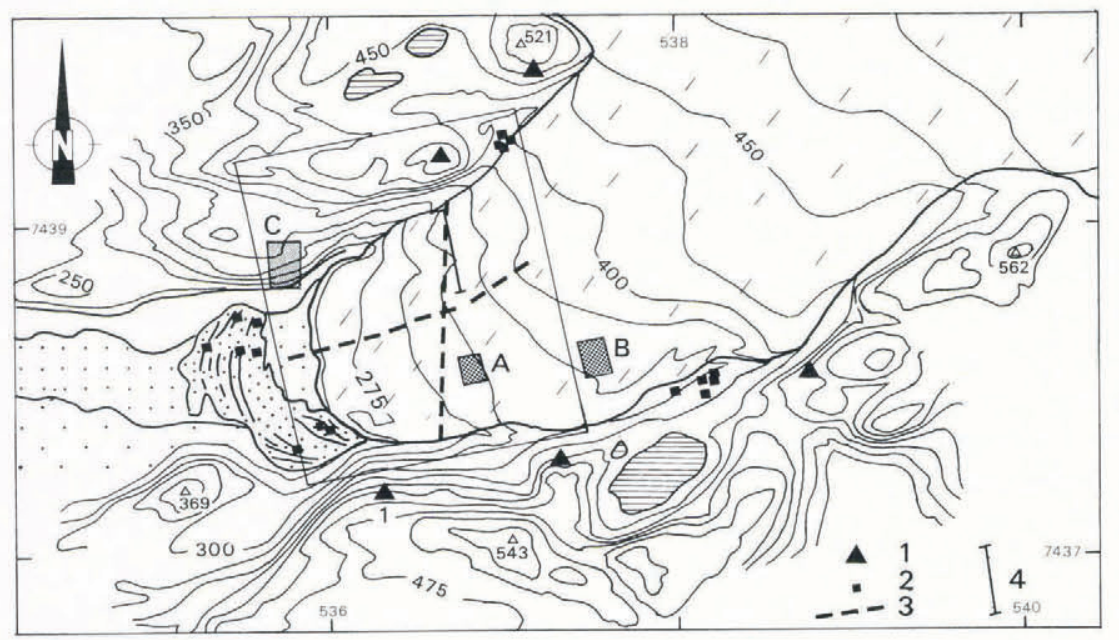

Fig. 2. Delailed map of the snoul of Leverett Glacier and its surroundings. 1. Control points of geodetic net; 2. points measured on lateral and frontal moraines; 3. longitudinal and transverse profile; 4. cross-section of supraglacial depression (Fig. 5). Area within rectangle is displayed in Figure 4. Coordinates in UTM $(\mathrm{km})$. 
independent and random, so that the relative uncertainty for altitude change can be calculated from

$$
\sigma_{z_{i j}}=\sqrt{{\overline{\mathrm{d} z_{i}}}^{2}+{\overline{\mathrm{d} z_{j}}}^{2}}
$$

where $i$ and $j$ represent the subsequent years.

The longitudinal and transverse profiles are measured on the aerial photographs using the $x$ and $y$ coordinates determined from the field survey in 1992.

To study the spatial pattern of elevation change, digital elevation models (DEMs) were constructed based on regular grid measurements. It was decided to use a grid spacing of $25 \mathrm{~m} \times 25 \mathrm{~m}$. In every stereo model approximately 5000 points were measured, with $40 \%$ on the surrounding ice-free surfaces. Some of these were used as an independent check on the accuracy of the altitudes obtained after interpolation to identical $x$ and $y$ coordinates. During the short time period under consideration, the rock surfaces do not change in elevation, and differences in altitude may be attributed to interpolation errors and inconsistent photogrammetric measurements. For a steep $\left(27^{\circ}\right)$ area west of the glacier snout (Fig. 2; area C) the differences in altitude are -1.4 , 1.4 and $0.0 \mathrm{~m}$ for the periods $1943-68,1968-85$ and $1943-$ 85 , respectively. These differences are very small considering that a small planimetrical error at these locations results in large differences in altitude.

To examine the effect of micro-relief (crevasses) at the glacier surface on the altitude measurements from regular grid measurements, we selected two areas, one without micro-relief (Fig. 2; area $\mathrm{A}$ ) and one within a highly crevassed region (Fig. 2; area B). On the 1968 photographs, we measured 231 points in area $\mathrm{A}$ and 211 points in area B. After interpolation to a $5 \mathrm{~m} \times 5 \mathrm{~m}$ grid using kriging as interpolation method, and averaging to the regular $25 \mathrm{~m} \times 25 \mathrm{~m}$ grid measurements, we compared the detailed measurements with regular grid values. For area $\mathrm{A}$, the difference between the regular grid and the denser measurements was $0.51 \pm 0.10 \mathrm{~m}$ number of $25 \times 25$ cells, $n=12$ ) and for area $\mathrm{B}$ $0.02 \pm 0.15 \mathrm{~m} \quad(n=32)$. In area $\mathrm{B}$, the absolute differences are much larger than in the low relief-area $\mathrm{A}$ area $\mathrm{B}$ : minimum $-2.2 \mathrm{~m}$, maximum $+1.2 \mathrm{~m}$; area A: minimum $-0.3 \mathrm{~m}$, maximum $+1.2 \mathrm{~m}$ ), but the sum of the differences is approximately zero due to spacing of crevasses. We can therefore assume that the glacier morphology is well represented by the $25 \mathrm{~m} \times 25 \mathrm{~m}$ grid.

\section{CHANGES IN ALTITUDE, POSITION AND SURFACE FEATURES}

From the transverse and longitudinal profiles (Fig. 3 and the DEMs (Fig. 4) altitude changes are calculated Table 2 ). Both methods show similar changes. The changes are smallest along the transverse profile, probably because this is not directly influenced by frontal changes (Table 2 .

Altitude changes are calculated for balance years from approximately September to August. The 1943 photographs were taken in spring before the start of the ablation season (Table 1). Therefore, the altitude of the glacier surface is $3.2 \mathrm{mw}$.e. too high compared to the situation at the end of the ablation season.

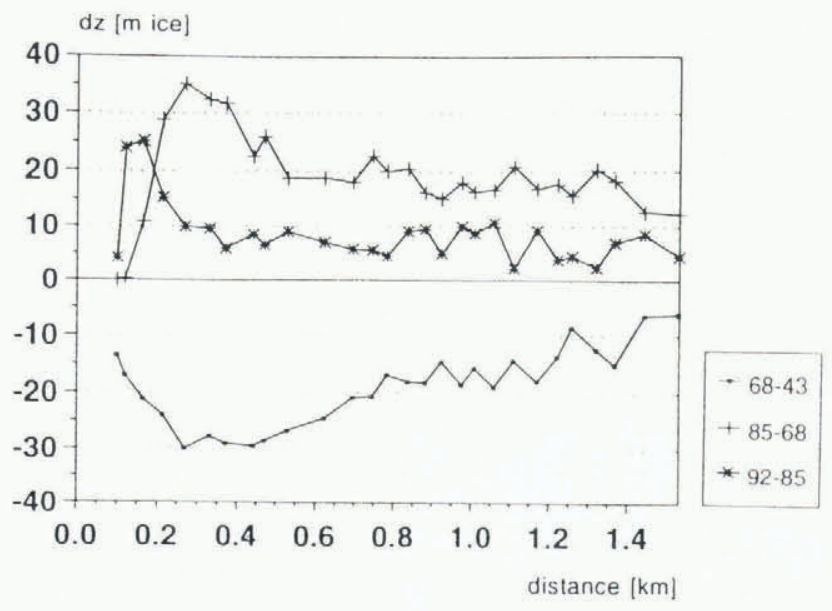

Fig. 3. Altitude differences between subsequent years for the longitudinal profile (position front is left in the figure).

Table 2. Altitude change and thickening or thinning rates, Leverett Glacier 1943-92

\begin{tabular}{|c|c|c|c|c|c|}
\hline \multicolumn{2}{|c|}{$1943 \quad 68$} & \multicolumn{2}{|c|}{$1968-85$} & \multicolumn{2}{|c|}{198592} \\
\hline $\mathrm{d} H$ & $\mathrm{~d} H / \mathrm{d} t$ & $\mathrm{~d} H$ & $\mathrm{~d} H / \mathrm{d} t$ & $\mathrm{~d} H$ & $\mathrm{~d} H / \mathrm{d} t$ \\
\hline mw.e. & m w.e. $a^{-1}$ & mw.e. & mw.e. $a^{-1}$ & mw.e. & mw.e. $a^{-1}$ \\
\hline $\begin{array}{l}6.3 \pm 0.1 \\
3.1 \pm 0.1)^{*}\end{array}$ & $\begin{array}{c}-0.6 \pm 0.004 \\
(-0.6 \pm 0.004)^{*}\end{array}$ & $+20.3 \pm 1.1$ & $+1.2 \pm 0.01$ & - & \\
\hline $\begin{array}{l}7.5 \pm 1.2 \\
4.3 \pm 1.2\end{array}$ & $\begin{array}{l}-0.7 \pm 0.05 \\
(-0.6 \pm 0.05)^{\ddagger}\end{array}$ & $+17.3 \pm 1.1$ & $+1.0 \pm 0.06$ & $\begin{array}{l}+6.4 \pm 0.5 \\
+3.4 \pm 0.5)^{\S}\end{array}$ & $\begin{array}{c}+0.9 \pm 0.06 \\
(+0.5 \pm 0.06)^{\S}\end{array}$ \\
\hline $\begin{array}{l}4.5 \pm 0.8 \\
1.3 \pm 0.8)^{\ddagger}\end{array}$ & $\begin{array}{l}-0.6 \pm 0.04 \\
(-0.5 \pm 0.04)^{*}\end{array}$ & $+14.1 \pm 0.7$ & $+0.8 \pm 0.05$ & $\begin{array}{l}+5.8 \pm 0.5 \\
(+2.81 \pm 0.5)^{\S}\end{array}$ & $\begin{array}{c}+0.8 \pm 0.07 \\
(+0.4 \pm 0.07)^{\S}\end{array}$ \\
\hline
\end{tabular}

\footnotetext{
* Mean of all points within area outlined in Figure 2.

${ }^{\dagger}$ Frontal $\pm 300 \mathrm{~m}$ are excluded from calculations.

Values corrected for measuring time in June 1943.

$\S$ Corrected values; see text for details.
} 
During the period 1943-68 the average amount of wasted ice on Leverett Glacier was $-16.3 \pm 0.1 \mathrm{~m}$ w.e. $(-13.1 \pm 0.1 \mathrm{~m}$ w.e. after correction for the time of the 1943 photography). The entire snout thinned uniformly. Thinning was largest at the front, decreasing up-glacier. The southern part of the glacier front shows the largest values of altitude decrease with a maximum of $47 \mathrm{~m}$ of ice in areas where ice completely disappeared (Fig. 4).

A thickening of $20.3 \pm 1.1 \mathrm{~m}$ w.e. was measured for the period 1968 85. The spatial pattern is similar to that of the previous period, but of opposite sign. Thickening continued during the period 1985-92, when the average altitude increased by $6.4 \pm 0.5 \mathrm{~m}$ w.e. $(3.1 \pm 0.5 \mathrm{~m}$ w.e. after correction; see below). Up to 1985 , these figures are based on the DEMs and after 1985 on the longitudinal profile.

The associated fluctuations of the ice margin are a retreat of $200-350 \mathrm{~m}$ during the period 1943-68; an advance of $150-200 \mathrm{~m}$ from 1968 to 1985 ; and an advance of about $175 \mathrm{~m}$ from 1985 to 1992 . The advance has eroded and overridden recessional (ice-cored) moraines deposited in the period 1943-68. Part of the thickening in the frontal area is therefore not the result of an increase in ice thickness, but of more elevated basal topography. The resistance to flow offered by the moraines and freezing of the glacier sole to the frozen substrate resulted in the development of a frontal bulge. The 1992 profile (Fig. 3) suggests that the advance of Leverett Glacier may continue.

Large supraglacial features can be studied with the use of the DEMs. One of these, a supraglacial depression, is located in the northern part of the glacier snout. The width of this depression is approximately $300 \mathrm{~m}$, and its depth compared to the surrounding higher ice surfaces is approximately $15 \mathrm{~m}$ (Fig. 5). The depression is the surface expression of a subglacial meltwater stream. The amount of meltwater transported within this channel is estimated to be $100-150 \mathrm{~m}^{3} \mathrm{~s}^{-1}$, which is about 2-3 times the amount of meltwater flowing from nearby Russell Glacier (Van de Wal and Russell, 1994). Such an amount of meltwater cannot be produced locally, indicating that the stream drains a large area compared to that of the outlet glacier. The outlet of the stream is at the north side of the front where a large tunnel develops during the summer. Probably, the supraglacial depression is generated by enhanced basal melting due to the frictional heat and the ice flow related to the closure of the

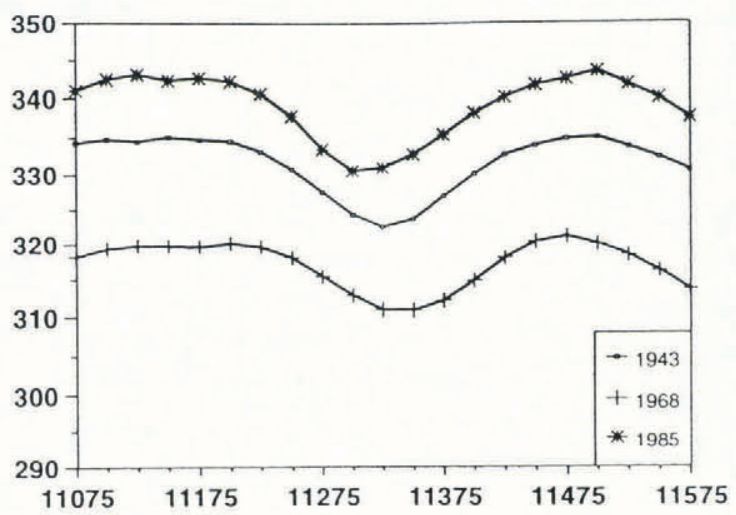

Fig. 5. Supraglacial depression in the northern part of the glacier snout. The profile location is indicated in Figure 2 (11075 is south and 11575 north).
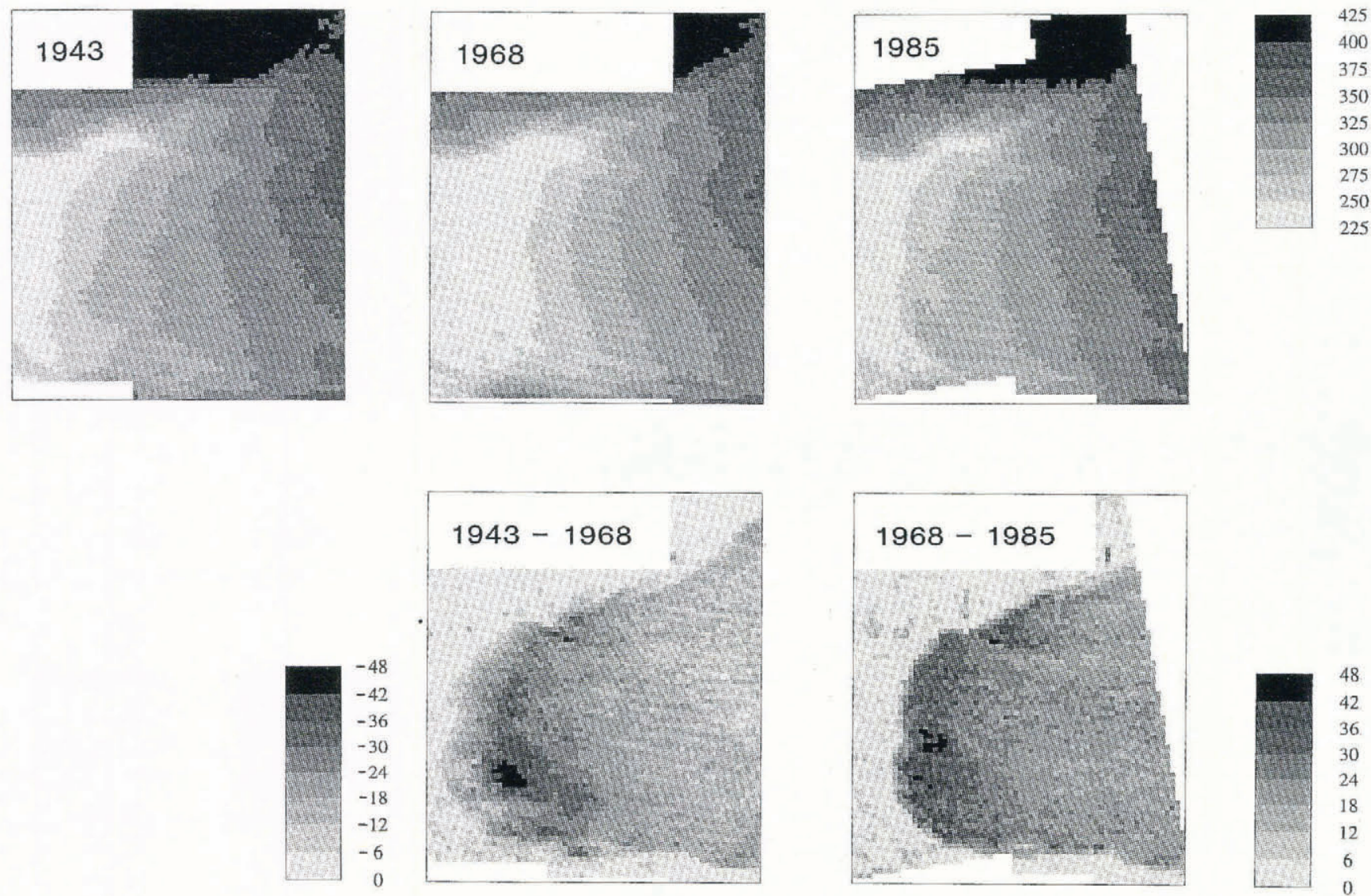

Fig. 4. Digital elevation models for the snout of Leveretl Glacier (top) and spatial pattern of altitude change (bottom). 
conduit. We have no information on the form of the channel. Based on geoelectrical soundings in front of Leverett Glacier, sediment thickness is at least $45-65 \mathrm{~m}$ ( Ph.D. thesis in preparation by F. Van Tatenhove). A subglacial channel with a gravel-boulder bed is therefore a likely possibility. From an elevation of $325 \mathrm{~m}$ and higher (in 1985), the lowest point of the depression shifted 25 $50 \mathrm{~m}$ towards the south contemporaneously with changes in ice thickness (Fig. 5). Despite these changes in ice thickness, the form of the depression does not change significantly. The position of the subglacial channel seems not very sensitive to changes in ice thickness. This could reflect the more regional supply of meltwater to this outlet as already suggested by Van de Wal and Russell (1994).

\section{IS THICKENING IN THE 1985-92 PERIOD REAL?}

To examine whether the thickening rate observed in the period 198592 can be attributed to natural variations in ablation, we use a method presented by Van der Veen (1993). Our assumptions are:

1. The variation in ablation rate is the only variable responsible for the observed thickening rate.

2. Ice flow and ice temperature do not change over the short interval under consideration (decades).

3. Ablation measured over three balance years on nearby Russell Glacier (Van de Wal, 1992; personal communication from M. R. Van den Broeke, 1994) reflects average conditions over at least one decade.

4. Variation in ablation is a random variable with zero mean.

To allow for the first assumption, we excluded the six frontal points of the longitudinal profile in 1992, because the increase in altitude is partially or entirely caused by a change in glacier geometry.

The measured change in altitude is $+6.4 \pm 0.5 \mathrm{~m}$ w.e. which corresponds to a thickening rate of $0.9 \pm 0.5 \mathrm{~m}$ w.e. $\mathrm{a}^{-1}$. This is probably too large considering the exceptional climatic conditions in 1985 and 1992. The summer of 1985 was warm compared to the 1942-92 average conditions. The mean air temperature during Junc-August was $10.1^{\circ} \mathrm{C}$ compared to an average of $9.0^{\circ} \pm 1.2^{\circ} \mathrm{C}( \pm 1 \sigma)$. For the months with monthly-mean positive air temperature (May October), the difference between 1985 and the long-term mean is larger, but still within two standard deviations of the mean value (1985: $8.0^{\circ} \mathrm{C}$ compared to $6.4^{\circ} \pm 1.2^{\circ} \mathrm{C}$ ). In contrast to the summer of 1985 , the summer of 1992 was relatively cold. June, July and August had an average temperature of $7.9^{\circ} \mathrm{C}$ and the months of May-October an average temperature of $4.4^{\circ} \mathrm{C}$. Altitude measurements following the warm summer of 1985 tend to underestimate the longterm trend in altitude change, while in 1992 the surface altitude is overestimated because of the relatively cold conditions. Therefore, the ablation conditions in 1985 and 1992 both tend to bias the measured altitude change towards thickening. The mean ablation on nearby Russell Glacier at an altitude of $341 \mathrm{~m}$ is $3.2 \mathrm{mw}$.e. $\mathrm{a}^{-1}$ with an absolute range of approximately $1.3 \mathrm{~m}$ ice (personal communication from M.R. Van den Broeke, 1994). When assuming that ablation varies annually with a maximum value of $1 \mathrm{~m}$ ice, this could indicate that $2 \mathrm{~m}$ of the $7 \mathrm{~m}$ measured altitude change can be explained by atypical ablation conditions in 1985 and 1992 the total ablation in 1992 was indeed less than the other annual totals in the period $1990-93$, as measured with ablation stakes along the GIMEX transect; personal communication from M. R. Van den Broeke, 1994).

The time of measurement in 1992 (10 and 11 July) must also be taken into account in the discussion of the value of the observed thickening. Based on seasonal measurements of ablation by Braithwaite and Olesen (1993), we estimate that at the time of our measurements about $48 \%$ of the total annual ablation had still to occur. Total ablation at Russell Glacier in 1992 was $2.5 \mathrm{~m}$ w.e. at $341 \mathrm{~m}$ altitude personal communication from M. R. Van den Broeke, 1994). The time of measurement halfway through the ablation season may thus account for an overestimate of surface altitude by approximately $1.3 \mathrm{~m}$ ice.

Taking into account the warm summer of 1985, the cold summer of 1992 and the time of measurement in 1992, the measured altitude change of $7.0 \pm 0.5 \mathrm{~m}$ ice is reduced to $3.6 \pm 0.5 \mathrm{~m}$ ice or a thickening rate of $0.5 \pm 0.070 \mathrm{~m}$ w.e. $\mathrm{a}^{\mathrm{l}}$.

Following Van der Veen (1993), the average thickness change over a period from time $t$ to $t+n \Delta t$ is given by the sum of yearly variations in ablation, $\delta A$ :

$$
\frac{\overline{\mathrm{d} H}}{\mathrm{~d} t}=\sum_{i=0}^{n-1} \delta A(t+i \Delta t) .
$$

The variable $\delta A$ is assumed to be random with zero mean and standard deviation $\sigma_{\delta A}$. Although neither the relaxation time nor the time lag between response and forcing for an outlet glacier within the ablation zone is known, it seems unlikely that changes in ice flow are important for a short time period of 7 years, and only the effect of variations in ablation needs to be considered.

The standard deviation of the rate of thickness change, $\sigma_{H}$, is then given by

$$
\sigma_{H}=\frac{\sigma_{\delta A}}{\sqrt{n}}
$$

The standard deviation of ablation variations, $\sigma_{\delta, A}$, for three West Greenland sites during the period 197789 is $0.61 \mathrm{mw} . \mathrm{a}^{-1}$ Braithwaite and others, 1992). The probability that the rate of thickness change exceeds

$$
\frac{\overline{\mathrm{d} H}}{\mathrm{~d} t} /\left(\sigma_{H} \sqrt{2}\right)
$$

is, according to Van der Veen (1993),

$$
P=\frac{1}{2}\left[1-\operatorname{erf}\left(\frac{\overline{\mathrm{d} H}}{\mathrm{~d} t} /\left(\sigma_{H} \sqrt{2}\right)\right)\right] .
$$

Table 3 lists this probability for several values of $\sigma_{\delta A}$ and $\mathrm{d} H / \mathrm{d} t \quad 0.32 \mathrm{~m}$ w.e. $\mathrm{a}^{-1}$ transverse profile and $0.5 \mathrm{~m}$ w.e. $\mathrm{a}^{-1}$ longitudinal profile).

This analysis reveals a probability of $7 \%$ that a (conservative) thickening rate of $0.32 \mathrm{mw}^{\mathrm{w}} \mathrm{e} . \mathrm{a}^{-1}$ is caused 
Table 3. The probability $P$ that a thickening rate of $0.5 \mathrm{~m} w . e . a^{-1}$ (longitudinal profile) and $0.32 \mathrm{~m} w . e . a^{-1}$ (transverse profile) in 7 years is caused by stochastic fluctuations in ablation

\begin{tabular}{|c|c|c|c|c|c|}
\hline \multirow[t]{2}{*}{$\sigma_{\delta A}$} & \multirow[t]{2}{*}{$\sigma_{H}$} & \multicolumn{2}{|c|}{$\frac{\overline{\mathrm{d} H}}{\mathrm{~d} t} /\left(\sigma_{H} \sqrt{2}\right)$} & \multicolumn{2}{|c|}{$P$} \\
\hline & & Longitudinal $^{\mathrm{d} t}$ & Transverse & Longitudinal & Transverse \\
\hline $\mathrm{ma}^{-1}$ & $\mathrm{~m}$ & $m^{-1} a^{-1}$ & $\mathrm{~m}^{-1} \mathrm{a}^{-1}$ & $\%$ & $\%$ \\
\hline 0.5 & 0.19 & 1.86 & 1.31 & 0.4 & 3.0 \\
\hline $0.61^{*}$ & $\underline{0.23}$ & $\underline{1.54}$ & $\underline{1.07}$ & $\underline{1.5}$ & $\underline{7.0}$ \\
\hline$\overline{1.0}$ & $\overline{0.38}$ & $\overline{0.93}$ & $\overline{0.65}$ & $\overline{9.1}$ & $1 \overline{1.0}$ \\
\hline 1.5 & 0.76 & 0.62 & 0.44 & 19.0 & 27.0 \\
\hline
\end{tabular}

" Underlined is the best estimate of $\sigma_{\delta A}$ for West Greenland (Braithwaite and others, 1992).

by stochastic variations in ablation. The measured thickening in the period 1985 92 must therefore be regarded as significant.

\section{REGIONAL CONTEXT OF ALTITUDE CHANGES}

Weidick (1991) and Weidick and others (1992) review the available information on recent changes of the marginal part of the ice sheet. From geological observations and mainly qualitative analysis of aerial photographs, the general pattern prior to 1950 is a recession of the inland ice. After 1950 an advance is observed over large areas of West Greenland. A summary of all the available data on rates of thickness change from photogrammetric or repeated levelling in ice-marginal areas in West Greenland is given in Table 4. Although measuring periods and methods differ from site to site, the trend as observed in the Leverett area can be recognised in Bauer and others (1968), Sechel (1977), Knudsen and

Table 4. Overview of available dala on thickness change from photogrammetric measurements or repeated levelling in West Greenland

\begin{tabular}{lll}
\hline Reference & Pocation & $\begin{array}{l}\mathrm{d} H / \mathrm{d} t \\
\text { mice a }^{-1}\end{array}$ \\
\end{tabular}

Bauer and others Ablation-zone (1968) EGIG line

Sechel (1977) Ablation-zone 195968

$-0.33$

EGIG line

Knudsen (1986) Nordbogletscher 1952/53-77+1.0

Nordbogletscher $1977-81+1.15$

Nordgletscher $\quad 1977-81+1.5-2.0$

Knudsen and Gothåbsfjord

$1968-80+1.7$

Moller (1982) area

Thomsen and others (1988)

This study
Moller (1982) and Knudsen (1986). The decrease in thickness measured by Thomsen and others (1988) in the Pâkitsoq area does not agree with other observations and emphasises the likely occurrence of regional and local deviations from any general trend.

Comparing the aerial photographs of 1943 and 1968, the 1943 photos show a more advanced position of Russell Glacier, the Isúnguata sermia and a $10 \mathrm{~km}$ long stretch of the ice margin south of Leverett Glacier (Fig. 6). The ice margin approximately reaches the 1943 position again in 1985. South of the Orkendalen outlet glacier, Scholz

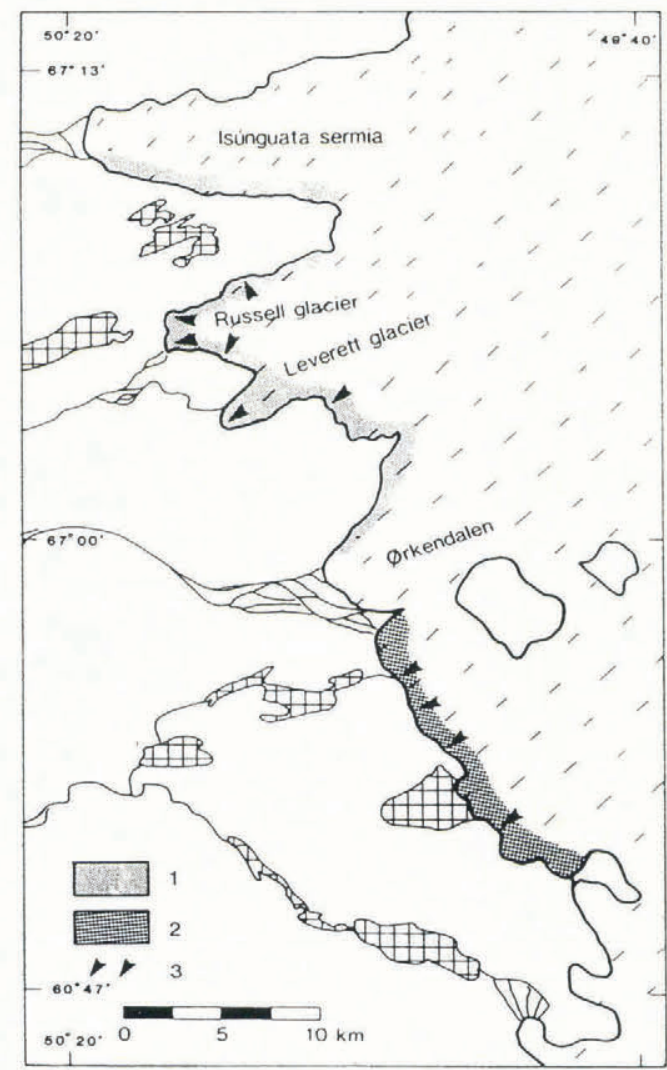

Fig. 6. Regional pattern of altitude change in central West Greenland as reported in literalure or extracted from aerial pholographs. See text for references. 1. Altitude change similar to Leverett Glacier for the period 1943 85; 2. altitude change similar for the period 1968-85; 3. evidence for advance after 1985 . 
(1991) observed an advancing ice margin over a stretch of $20 \mathrm{~km}$ from comparison of the 1968 photographs with field observations in 1986 and 1987.

Therefore, it seems reasonable to suggest that the changes in frontal position measured from 1943 to 1985 on Leverett Glacier are representative for the immediate vicinity,

Observations of Scholz (1991) in 1987, demonstrate that the advance was still in progress south of the Orkendalen. North of Leverett Glacier, photographs taken by Ten Brink (1971, plate 12-C) during fieldwork in the period 1969-70 show a large frontal lake at the front of Russell Glacier. This lake became progressively smaller from 1989 to 1992 . During the same period, the position to which Russell Glacier advances during the winter shifted farther west as documented by erosional features of temporary frontal meltwater streams. In fact the location of the front of Russell Glacier has reached its most westerly position since the winter of 1992/93. Regional information on ice-marginal changes during the period 1985-92 is more scattered (only observations of Russell Glacier and Orkendalen are available), and accordingly we cannot extend the measured thickening at Leverett Glacier to a larger area.

\section{GONGLUSIONS}

The data on the altitude changes of Leverett Glacier presented here are the first in West Greenland that span a time period of nearly 50 years.

During the period 194368 the rate of altitude change was $-0.6 \mathrm{~m}$ w.e. $\mathrm{a}^{-1}$. The thickening rate in the period 1968 85 was $+1.2 \mathrm{~m}$ w.e. $\mathrm{a}^{-1}$. Thickening continued during the period 198592 with a rate of $+0.4 \mathrm{~m}$ w.e. $\mathrm{a}^{-1}$.

Air-temperature data from a meteorological station approximately $20 \mathrm{~km}$ west of Leverett Glacier (Kangerlussuaq) is used to explain the role of local ablation conditions in the observed changes. The average summer temperature (May-September) was relatively high during the period 1943-68 and again during 1986-92. The intervening period, 1969-85, was relatively cold Fig. 7; Table 5). If there exists a correlation between air temperature and ablation, the observed changes in elevation are consistent with the trends in air temperature except for the most recent period (1985-92). The recent

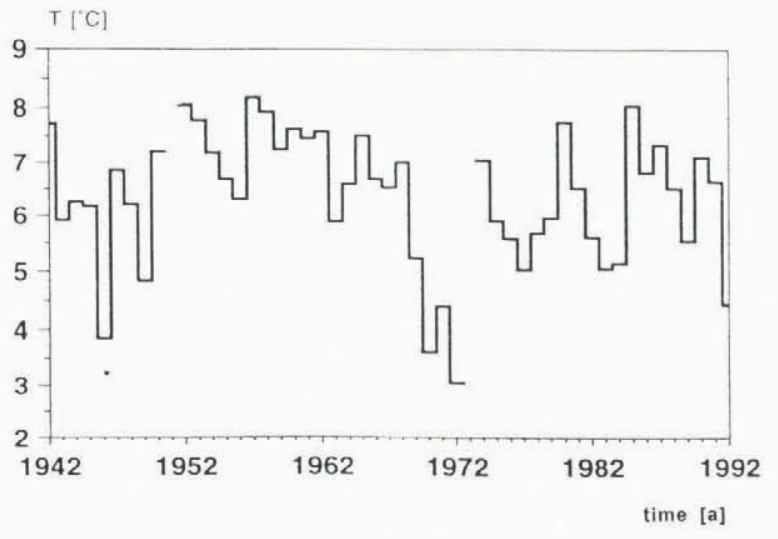

Fig. 7. Average May-Seplember temperature in Kangerlussuaq in the period 1942-92.

thickening requires increased inflow of ice from upstream to compensate for normal or higher ablation rates.

During the period 1943 85, the measured changes in altitude and position of the ice margin at Leverett Glacier have their equivalent along an approximately $40 \mathrm{~km}$ stretch of the ice-sheet margin in central West Greenland. This suggests that the observed trends reflect ice-sheet behaviour on a regional scale. Regional information on ice-marginal changes during the period 1985-92 is more scattered, and accordingly we cannot extend the measured thickening at Leverett Glacier for this period to a larger area.

\section{ACKNOWLEDGEMENTS}

The field assistance and inspiring company of all participants during the six weeks near the Leverett is highly appreciated. The Institute for Marine and Atmospheric Research, Utrecht University (M. R. Van den Broeke), provided mass-balance measurements of Russell Glacier. Unpublished temperature and precipitation data for Kangerlussuaq were kindly provided by N. Thingvad of the Database Section, Danish Meteorological Institute (DMI), Copenhagen. Climate data for Kangerlussuaq before 1972 were made available by the U.S. National Climatic Data Center, Asheville, NC, U.S.A. The Dutch National Research Program Global Air Pollution and Climate Change provided funding for the first author

Table 5. Climate statistics from Kangerlussuaq for periods identical to the aerial-photograph intervals

\begin{tabular}{|c|c|c|c|c|c|}
\hline $\begin{array}{l}\text { Mean annual } \\
\text { air temperature }\end{array}$ & $\begin{array}{l}\text { Annual precip- } \\
\text { ilation }\end{array}$ & $\begin{array}{l}\text { T (June- } \\
\text { August) }\end{array}$ & $\begin{array}{l}T \text { (May- } \\
\text { September) }\end{array}$ & $\begin{array}{l}T \text { (June } \\
\text { Augusl) }\end{array}$ & $\begin{array}{c}T(\text { May } \\
\text { Seplember })^{*}\end{array}$ \\
\hline${ }^{\circ} \mathrm{C}$ & $\mathrm{mm}$ & C & ${ }^{\circ} \mathrm{C}$ & ${ }^{\circ} \mathrm{C}$ & C \\
\hline
\end{tabular}

\begin{tabular}{lllllll}
\hline $1942-92$ & $-5.2 \pm 0.2$ & $155 \pm 7$ & & & & \\
$1943-68$ & $-4.8 \pm 0.2$ & $169 \pm 12$ & $+9.3 \pm 0.2$ & $+6.8 \pm 0.2$ & $-0.15 \pm 0.24$ & $-0.12 \pm 0.20$ \\
$1969-85$ & $-5.6 \pm 0.5$ & $159 \pm 15$ & $+8.2 \pm 0.3$ & $+5.6 \pm 0.3$ & $-1.22 \pm 0.26$ & $-1.31 \pm 0.31$ \\
$1986-92$ & $-5.3 \pm 0.5$ & $148 \pm 13$ & $+9.2 \pm 0.3$ & $+6.3 \pm 0.4$ & $-0.28 \pm 0.28$ & $-0.56 \pm 0.35$
\end{tabular}

"For periods from September to August.

* Temperature as deviation from reference period 1951-70. 
(contract 276/91-NOP). Field-work in Greenland by C. Roelfsema was supported by the Molengraaff Fund.

\section{REFERENCES.}

Bauer, A., W. Ambach and O. Schimpp. 1968. Mouvement et variation d'altitude de la zone d'ablation ouest. Medd. Gronl., $174(1)$.

Braithwaite, R.J. and O.B. Olesen. 1993. Seasonal variation of ice ablation at the margin of the Greenland ice sheet and its sensitivity to climate change, Qamanârssûp sermia, West Greenland. J. Glaciol., 39 (132), 267-274.

Braithwaite, R.J., O.B. Olesen and H.H. Thomsen. 1992. Calculated variations of annual ice ablation at the margin of the Greenland ice sheet, West Greenland, 1961-90. J. Glaciol., 38 129), 266272.

Brink, N. W. ten. 1971. Holocene deleveling and glacial history between Sondre Stromfjord and the Greenland ice sheet. (Ph.D. thesis, University of Washington, Seattle.

Knudsen, N.T. 1986. Recent changes of Nordbogletscher and Nordgletscher, Johan Dahl Land, south Greenland. Ann. Glaciol., 8, $106-110$.

Knudsen, N. T. and J. T. Moller. 1982. Photogrammetric survey of
Qamanârssûp sermia. Gronlands Geologiske Undersogelse. GletscherHydrologiske Meddelelser 82/4, 1-26.

Scholz, H. 1991. Ein Vorstoß des Inlandeises in Westgrönland. Dokumentation des vorrückenden Eisrandes bei Sondre Stromfjord. Eiszeitalter Ggw., 41, 119-131.

Seckel, H. 1977. Höhenänderungen im grönländischen Inlandeis zwischen 1959 und 1968. Medd. Gronl., $187(4)$.

Thomsen, H.H., L. Thorning and R.B. Braithwaite. 1988. Glacierhydrological conditions on the inland ice northeast of Jacobshavn/ Ilulissat, West Greenland. Gronlands Geologiske Undersogelse. Rapport 138.

Veen, C.J. van der. 1993. Interpretation of short-time ice-sheet elevation changes inferred from satellite altimetry. Climalic Change, 23 4), 383-405.

Wal, R.S.W. van de. 1992. Ice and climate. (Ph.D. thesis, Utrecht University.)

Wal, R.S.W. van de and A.J. Russell. 1994. A comparison of energy balance calculations, measured ablation and meltwater runoff, Sondre Stromfjord, West Greenland. Global and Planetary Change, 9 $1-2), 29-38$.

Weidick, A. 1991. Present-day expansion of the southern part of the inland ice. Gronlands Geologiske Undersogelse. Rapport 152, 73-79.

Weidick, A., C. E. Boggild and N. T. Knudsen. 1992. Glacier inventory and atlas of West Greenland. Gronlands Geologiske Undersogelse. Rapport 158. 